\title{
VEGETATION RESPONSES TO SUPPLEMENTAL WINTER FEEDING OF ELK IN WESTERN WYOMING
}

\author{
Matthew J. Rinella ${ }^{1}$, Ron Dean ${ }^{2}$, Marty Vavra ${ }^{3}$, and Catherine G. Parks ${ }^{4}$
}

\begin{abstract}
To compensate for losses in overwintering habitat, elk are fed hay in winter at approximately 37 locations throughout the western United States. These winter feeding programs concentrate elk activity, and there is concern that such concentrations could degrade plant communities. Except for one study focused exclusively on aspen (Populus tremuloides), ours is the first to quantify vegetation responses to supplemental winter feeding of elk. The western Wyoming feedground we studied was established in winter 1981-1982, and supplemental feeding occurred every winter through 2006. Transects were arranged in a before-after control-impact (BACI) design, and vegetation data were gathered in the midsummers of 1981 and 2006. Over the study period, the feedground became invaded by smooth brome (Bromus inermis), a nonnative grass constituent of hay fed to the elk. The smooth brome invasion was attended by declines in native forb cover and the apparent extirpation of shrubs from the feedground. The smooth brome invasion did not extend beyond the feedground, but an area $125 \mathrm{~m}$ from the feedground showed decreases in shrubs. At areas $\geq 750 \mathrm{~m}$ from the feedground, forbs and shrubs did not decrease demonstrably, and in some cases they showed evidence of increasing over the study period. Supplemental winter feeding at a feedground in western Wyoming degraded the plant community, but, with the possible exception of aspen, the degradation did not appear to extend great distances beyond the small area where the animals were fed.
\end{abstract}

RESUMEN.-Para compensar las pérdidas en el hábitat de hibernación, se alimenta a los alces con heno durante el invierno en aproximadamente 37 sitios a lo largo del occidente de los Estados Unidos. Estos programas de alimentación invernal concentran la actividad del alce, y existe la preocupación de que estas concentraciones puedan degradar a las comunidades vegetales. Con la excepción de un estudio enfocado exclusivamente en el álamo temblón (Populus tremuloides), nuestro estudio es el primero en cuantificar las respuestas de la vegetación hacia la alimentación invernal suplementaria del alce. El área de alimentación al occidente de Wyoming que estudiamos se estableció durante los inviernos de 1981 y 1982, y se efectuó una alimentación suplementaria durante cada invierno hasta 2006. Los transectos se hicieron de acuerdo con un diseño BACI (before-after control-impact, por sus siglas en inglés) y los datos de la vegetación se recopilaron a mediados de los veranos de 1981 y de 2006. Durante el período del estudio, el área de alimentación fue invadida por Bromus inermis (bromo suave), un pasto nonativo componente del heno que alimenta a los alces. La invasión de bromo suave estuvo acompañada por disminuciones en la cobertura de plantas herbáceas nativas y la aparente extirpación de arbustos del área de alimentación. La invasión de bromo suave no se extendió más allá del área de alimentación; pero, una zona a $125 \mathrm{~m}$ del área de alimentación mostró una disminución de arbustos. En zonas a 750 metros del área de alimentación,los arbustos y hierbas no decrecieron notablemente, y en algunos casos mostraron evidencia de incremento durante el periodo de estudio. La alimentación invernal suplementaria en las áreas de alimentación al oeste de Wyoming degradó la comunidad vegetal, pero con la posible excepción del álamo temblón, tal degradación no aparentó extenderse a distancias mucho más allá de la pequeña área en donde se alimentó a los animales.

Elk are fed hay in winter at approximately 37 locations in the western United States (Smith 2001). The feeding is primarily done to compensate for losses in overwintering habitat and to reduce damage to agricultural lands. Supplemental winter feeding can increase elk survival (Smith and Anderson 1998) as well as elk viewing and hunting opportunities, and it can prevent vehicle-elk collisions by improving control of elk migrations (Smith 2001). However, these benefits are offset by major deficits, including increased disease transmission among elk (Cross et al. 2010, Scurlock and Edwards 2010) and the expense of feeding the animals (Smith 2001). Also, if feeding increases winter survival and causes elk numbers to increase, it could also lead to overgrazing of areas elk inhabit in spring, summer, and fall.

Another potential downside to supplemental winter feeding is elk concentration on and near feedgrounds, which may harm plant communities. The hypothesis that supplemental winter feeding of ungulates harms plant communities is supported by Doenier et al. (1997),

${ }^{1}$ Rangeland Scientist, USDA Agricultural Research Service, Fort Keogh Livestock \& Range Research Laboratory, 243 Fort Keogh Road, Miles City, MT 59301.Email: matt.rinella@ars.usda.gov

${ }^{2}$ Wildlife Biologist (retired), Wyoming Department of Game and Fish, Alpine, WY 83128

32Rangeland Scientist, USDA Forest Service, Pacific Northwest Research Station, 1401 Gekeler Lane, La Grande, OR 97850.

${ }^{4}$ Research Ecologist, USDA Forest Service, Pacific Northwest Research Station, 1401 Gekeler Lane, La Grande, OR 97850. 


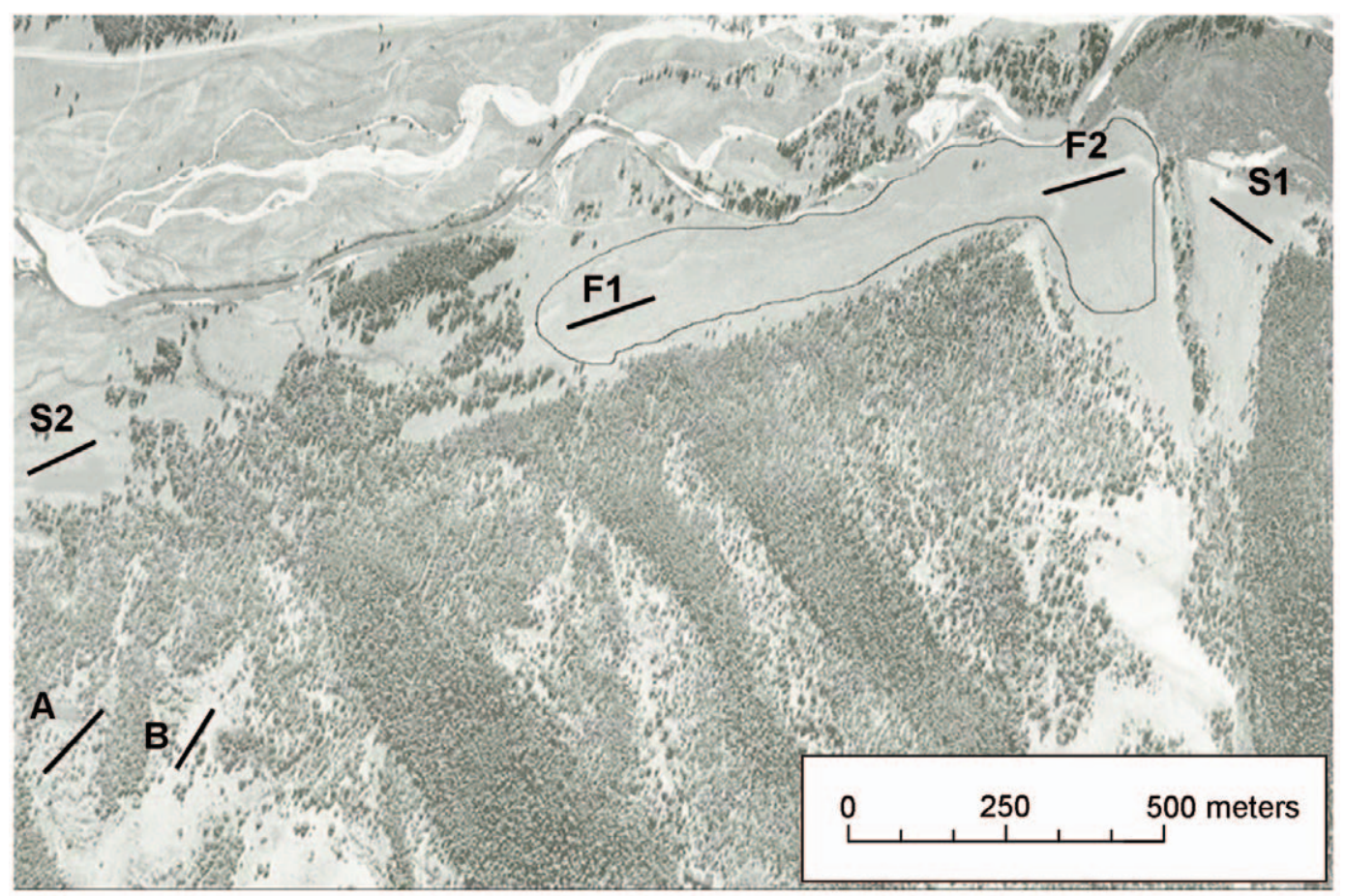

Fig. 1. Western Wyoming feedground (circled area) where elk were fed hay in winter. To quantify vegetation responses to elk feeding, transects on the feedground (F1, F2) and transects in nearby sagebrush (S1, S2), bunchgrass (B), and aspen (A) habitats were measured before feeding began and again after 25 years of annually repeated feeding.

who examined decreasing browsing damage with increasing distance from a white-tailed deer feedground, and by Romme et al. (1995), who showed increasing woody plant vigor with increasing distance from elk overwintering grounds. Conversely, the hypothesis is not supported by Barnett and Stohlgren (2001), whose study failed to show a relationship between aspen (Populus tremuloides) regeneration and distance from elk feedgrounds.

We quantified changes in plant community composition caused by 25 years of supplemental winter feeding of elk in western Wyoming. Our goal was to estimate vegetation changes on the feedground as well as at several locations at various distances from the feedground. We hypothesized that negative effects of feeding would be quite severe on the feedground and less severe off the feedground.

\section{METHODS}

\section{Study Area}

A feedground was established approximately $53 \mathrm{~km}$ south of Alpine, Wyoming, during the winter of 1981-1982 (Fig. 1). The feedground was located on a 10-ha sagebrush (Artemisia tridentata ssp. vaseyana) flat at 2408 m elevation. The feedground was surrounded by lodgepole pine (Pinus contorta) stands to the north and west and by riparian vegetation dominated by Salix spp. to the south and east. The area was annually grazed by cattle from late August to early October. Each year, between 700 and 1000 elk were fed a mix of alfalfa (Medicago sativa), orchardgrass (Dactylis glomerata), and smooth brome (Bromus inermis) hay every day from early December to late April. Horse-drawn wagons were used to spread the hay about the feedground. Between 363,000 and 454,000 kg of hay were distributed each year.

\section{Data Collection}

Six permanent $30-\mathrm{m}$ transects were arranged in a before-after control-impact (BACI) design in summer 1981 (Green 1979). Two transects were on the feedground (F1, F2), 2 were on sagebrush sites with species composition similar to the feedground (S1, $125 \mathrm{~m}$ from feedground; $\mathrm{S} 2,750 \mathrm{~m}$ from feedground), and 2 were on the 
locations nearest the feedground that were dominated by bluebunch wheatgrass (Pseudoroegneria spicata; B, $1500 \mathrm{~m}$ from feedground) and aspen (A, $1600 \mathrm{~m}$ from feedground; Fig. 1). Midsummer in 1981 and in 2006, we estimated cover of native and nonnative grasses and native forbs along each transect in ten $0.3 \times 0.6-\mathrm{m}$ frames spaced at 3-m intervals. Native shrub cover was estimated by recording the number of instances a tape measure intercepted shrubs at 1200 evenly spaced points along each transect. On the aspen site, number and diameters of aspen stems was recorded in a $6 \times 30$-m area centered on the transect. Diameters were measured $1.4 \mathrm{~m}$ above the ground on the upslope side of stems.

\section{Analysis}

Because the cover data did not follow a standard probability distribution (i.e., the data contained many zeros and were restricted to the $0 \%-100 \%$ interval), we used nonparametric statistics (i.e., bootstrap confidence intervals) to estimate changes in cover between 1981 and 2006 (Efron and Tibshirani 1993, Hjorth 1994). We acquired 10,000 bootstrap samples for each cover variable on each transect by repeatedly (1) calculating the mean of 10 plots sampled randomly with replacement from the transect's 2006 data and (2) subtracting this mean from the mean of 10 plots sampled randomly with replacement from the transect's 1981 data. This approach was modified slightly for F1 and F2 because these transects were both located on the feedground and were expected to respond similarly to supplemental feeding. The means of each F1 and F2 bootstrap sample were then averaged, so plant cover changes for the feedground were estimated by averaging over F1 and F2. Histograms of the bootstrap samples indicated bootstrap confidence intervals could be derived via the percentile method without correcting for bias or skew (Dixon 2001). When all observations on a plant group equaled zero at both time points, we assumed the plant group was absent from the transect for the entire study.

\section{Results}

Over the study period, the feedground became invaded by smooth brome, a nonnative grass constituent of the hay fed to the elk (Fig. 2, sample means; Fig. 3, statistical estimates).
Conversely, areas sampled outside the feedground were not invaded by smooth brome (Figs. 2, 3).

The smooth brome invasion was attended by declines in native forb and shrub cover over the study period on the feedground $(\mathrm{F} 1, \mathrm{~F} 2$ of Figs. 2, 3). Shrub cover also declined at the sagebrush site $125 \mathrm{~m}$ from the feedground, while forb cover increased at this site (S1 of Figs. 2, 3). Forb and shrub cover did not change demonstrably over the study period at the sagebrush site $750 \mathrm{~m}$ from the feedground (S2 of Figs. 2, 3). At the bunchgrass and aspen sites, forb and shrub cover did not decrease demonstrably over the study period, and in some cases these groups showed evidence of increasing (B, A of Figs. 2, 3).

With a sample size of 1 at each time point, our aspen data were not amenable to statistical analysis. Within the aspen plot, stem densities increased over the study period in most diameter classes (Fig. 4). The mean diameter within the largest size class $(>2.54 \mathrm{~cm})$ declined from $18 \mathrm{~cm}$ in 1981 to $7 \mathrm{~cm}$ in 2006.

\section{Discussion}

The feeding of hay almost certainly caused frequent, large influxes of smooth brome seed, and this likely promoted the smooth brome invasion of the feedground (Williamson and Fitter 1996, Lonsdale 1999). Moreover, winter elk browsing may have further promoted the smooth brome invasion by reducing shrub production (Singer and Renkin 1995, Wambolt and Sherwood 1999), thereby opening niches for smooth brome (Dantonio 1993, Gross et al. 2005). Another contributing factor may have been increased safe site availability for smooth brome seedling establishment owing to elk disturbances to soil (Oesterheld and Sala 1990, Hayes and Holl 2003). Both the large seed influxes and the disturbances may have been necessary prerequisites for smooth brome invasion, as propagule pressure and disturbance can positively interact to promote invasions (Clark and Johnston 2009).

Our results suggest that large effects of elk feeding on native shrubs extended short distances not exceeding $750 \mathrm{~m}$ beyond the feedground. Particularly, shrubs declined over the study period at the site $125 \mathrm{~m}$ from the feedground, but forbs and shrubs did not demonstrably decline, and in some cases showed evidence 

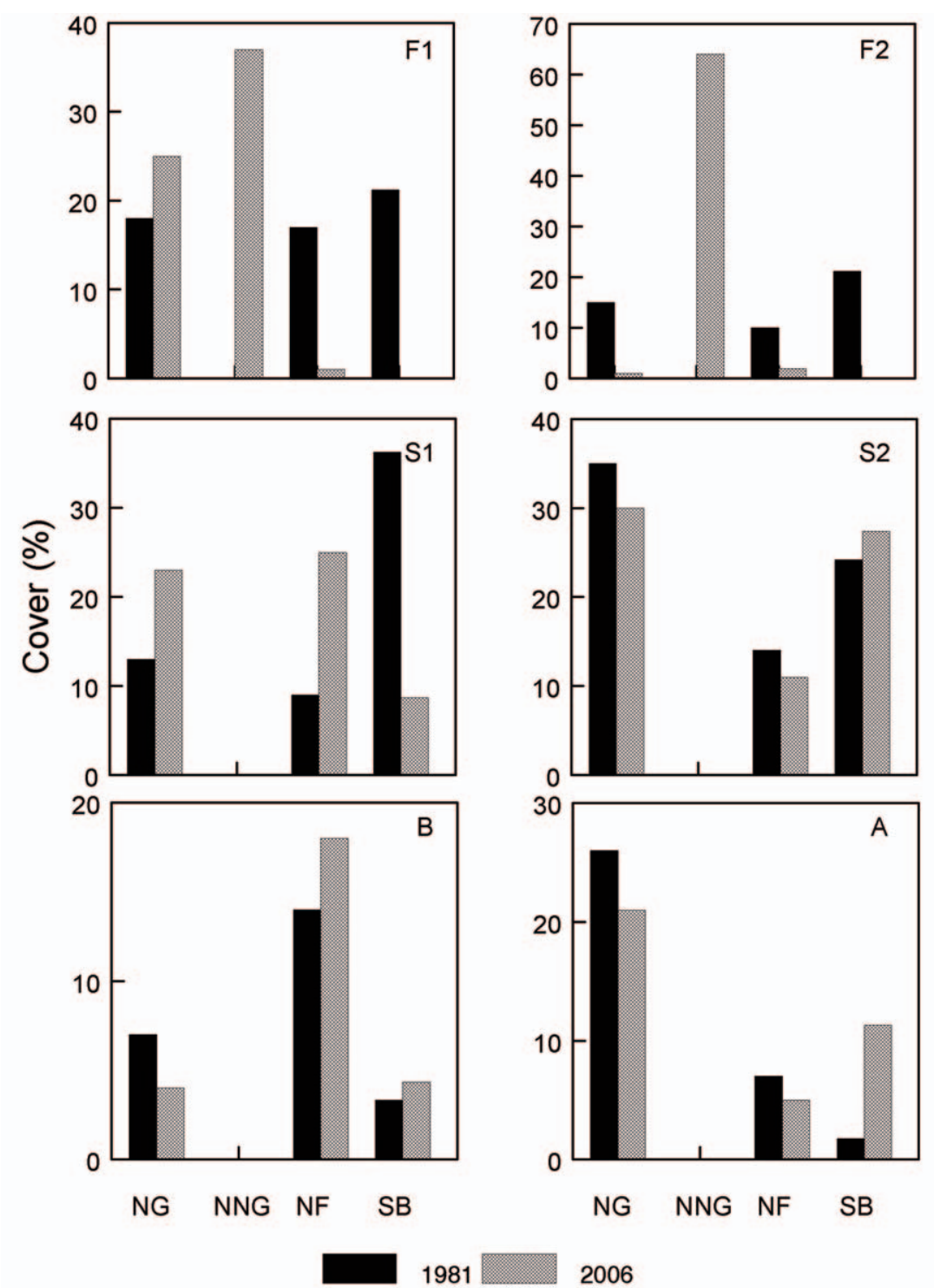

Fig. 2. Mean percent cover of native grasses (NG), nonnative grasses (NNG), native forbs (NF), and shrubs (SB) along transects on the feedground (F1, F2) and transects in nearby sagebrush (S1, S2), bunchgrass (B), and aspen (A) habitats.

of increasing, at sites $\geq 750 \mathrm{~m}$ from the feedground. These results provide strong evidence that some aspect of the elk feeding program was responsible for native forb and shrub reductions on and adjacent to the feedground. It may be that competition from smooth brome reduced the forbs and shrubs (Larson and Larson 2010). It is also possible that elk grazing reduced the shrubs (Singer and Renkin 1995, Wambolt and Sherwood 1999); however, it is unlikely that elk grazing reduced the forbs because they would have generally been dormant when elk were concentrated on the feedground.

Whereas the density of aspen stems appeared to increase within most size classes over the study period, the mean diameter in the largest size class declined from $18 \mathrm{~cm}$ to $7 \mathrm{~cm}$. This finding is consistent with elk removing the largest stems, thereby promoting a flush of small stems. The small stems were likely covered with snow when the feeding program concentrated elk in the area, which would have rendered the 


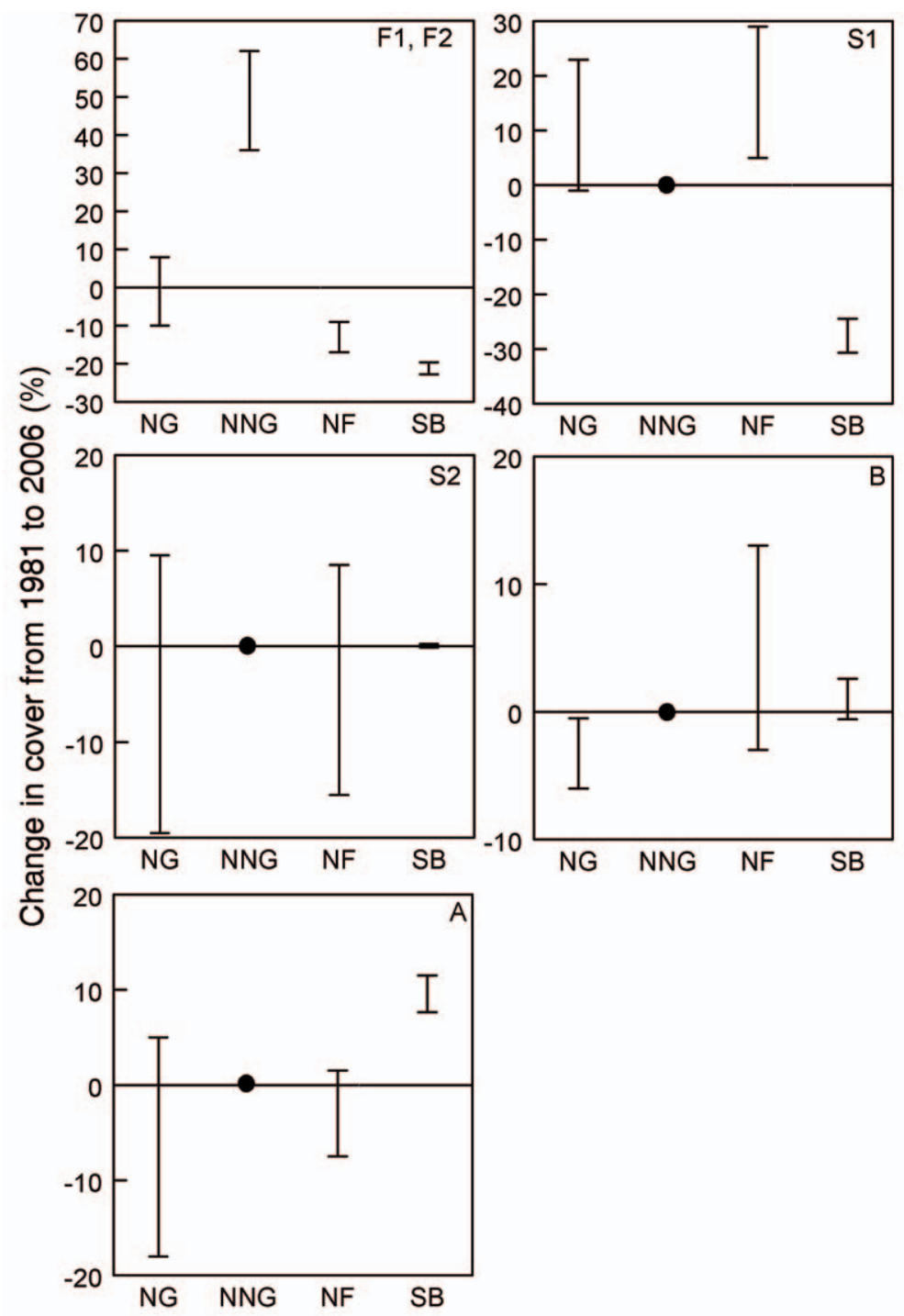

Fig. 3. 95\% bootstrap confidence intervals estimating effects of supplemental winter feeding of elk on percent cover of native grasses (NG), nonnative grasses (NNG), native forbs (NF), and shrubs (SB). Vegetation changes between 1981 and 2006 were measured within transects on the feedground (F1, F2) and transects in nearby sagebrush (S1, S2), bunchgrass (B), and aspen (A) habitats. Dots represent plant groups that were absent from transects at both sampling times.

small stems mostly immune to browsing damage. Ultimately, our conclusions regarding aspen are highly provisional, because elk browsing is just one of a number of factors that could have caused changes in the aspen size class distribution over the study period. Barnett and Stohlgren (2001) also failed to detect a relationship between aspen regeneration and distance from feedgrounds.

Because of the relatively high elevation of the feedground we studied, snowdepths were generally great during the supplemental feeding period. Deep snow likely concentrated elk activity close to the feedground. Vegetation damage may extend greater distances at lower elevation feedgrounds where shallower snow confers less protection to plants and allows elk to wander farther from the feedground.

Supplemental winter feeding of wild ungulates is done at many locations in the United States to offset declines in overwintering habitat and reduce starvation. Supplemental feeding 


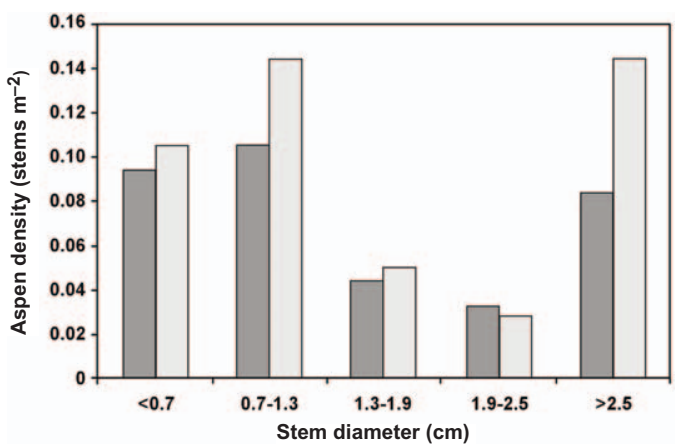

Fig. 4. Densities of aspen trees in a plot located $1600 \mathrm{~m}$ from a feedground where elk were annually fed hay in winter between 1981 (dark bars) and 2006 (light bars).

can concentrate animals in small areas, and there is concern that the concentrated activity could degrade plant communities. We found that supplemental winter feeding of elk reduced forbs and shrubs and fostered invasion by a nonnative grass, but these effects appeared to extend only short distances beyond the feedground. Indeed, supplemental feeding damaged native plant communities, but our study shows that severe damage to native forbs and shrubs does not always radiate great distances beyond the small areas where the animals are fed. To protect these small areas and prevent nonnative plant invasions of larger areas, our data suggest it is good practice not to feed elk smooth brome or any other nonnative species that is capable of invading western U.S. plant communities. The absence from the feedground of naturalized populations of our study's other hay species (i.e., alfalfa, orchardgrass) suggests that these species are good options, and there are likely many other options.

\section{Literature Cited}

Barnett, D.T., and T.J. Stohlgren. 2001. Aspen persistence near the National Elk Refuge and Gros Ventre Valley elk feedgrounds of Wyoming, USA. Landscape Ecology 16:569-580.

ClakK, G.F., And E.L. Johnston. 2009. Propagule pressure and disturbance interact to overcome biotic resistance of marine invertebrate communities. Oikos 118: 1679-1686.

Cross, P.C., E.K. Cole, A.P. Dobson, W.H. Edwards, K.L. Hamlin, G. Luikart, A.D. Middleton, B.M SCURLOCK, AND P.J. White. 2010. Probable causes of increasing brucellosis in free-ranging elk of the
Greater Yellowstone Ecosystem. Ecological Applications 20:278-288.

Dantonio, C.M. 1993. Mechanisms controlling invasion of coastal plant communities by the alien succulent Carpobrotus edulis. Ecology 74:83-95.

Dixon, P.M. 2001. The bootstrap and the jackknife: describing the precision of ecological indices. Pages 267-288 in S.M. Scheiner and J. Gurevitch, editors, Design and analysis of ecological experiments. Oxford University Press, New York, NY.

Doenier, P.B., G.D. DelGuidice, And M.R. RigGs. 1997. Effects of winter supplemental feeding on browse consumption by white-tailed deer. Wildlife Society Bulletin 25:235-243.

Efron, B., And R. Tibshirani. 1993. An introduction to the bootstrap. Chapman \& Hall, New York, NY.

GreEN, R.H. 1979. Sampling design and statistical methods for environmental biologists. John Wiley \& Sons, New York, NY

Gross, K.L., G.G. Mittelbach, and H.L. Reynolds. 2005. Grassland invasibility and diversity: responses to nutrients, seed input, and disturbance. Ecology 86: $476-486$.

Hayes, G.F., AND K.D. HoLL. 2003. Cattle grazing impacts on annual forbs and vegetation composition of mesic grasslands in California. Conservation Biology 17 : 1694-1702.

HJORTH, J.S.U. 1994. Computer intensive statistical methods. Chapman \& Hall, London.

Larson, D.L., And J.L. LaRson. 2010. Control of one invasive plant species allows exotic grasses to become dominant in northern Great Plains grasslands. Biological Conservation 143:1901-1910.

LONSDALE, W.M. 1999. Global patterns of plant invasions and the concept of invasibility. Ecology 80:1522-1536.

Oesterheld, M., AND O.E. SALA. 1990. Effects of grazing on seedling establishment: the role of seed and safesite availability. Journal of Vegetation Science 1: 353-358.

Romme, W.H., M.G. Turner, L.L. Wallace, and J.S. WALKER. 1995. Aspen, elk, and fire in northern Yellowstone Park. Ecology 76:2097-2106.

SCURLOCK, B.M., AND W.H. EDWARDS. 2010. Status of brucellosis in free-ranging elk and bison in Wyoming. Journal of Wildlife Diseases 46:442-449.

SINGER, F.J., AND R.A. RENKIN. 1995. Effects of browsing by native ungulates on the shrubs in big sagebrush communities in Yellowstone National Park. Great Basin Naturalist 55:201-212.

Sмith, B.L. 2001. Winter feeding of elk in western North America. Journal of Wildlife Management 65:173-190.

SMITH, B.L., AND S.H. ANDERSON. 1998. Juvenile survival and population regulation of the Jackson elk herd. Journal of Wildlife Management 62:1036-1045.

Wambolt, C.L., And H.W. Sherwood. 1999. Sagebrush response to ungulate browsing in Yellowstone. Journal of Range Management 52:363-369.

Williamson, M.H., AND A. FitTER. 1996. The characters of successful invaders. Biological Conservation 78 : $163-170$.

Received 15 June 2011 Accepted 21 November 2011 